\title{
Lower Faecal Egg Excretion in Chemically-induced Diabetic Mice Infected with Schistosoma mansoni Due to Impaired Egg Maturation
}

\author{
Maarten Hulstijn ${ }^{+}$, Regina Maria F de Oliveira*, Egberto G de Moura**/++, \\ José Roberto Machado-Silva*/++
}

Curso de Biologia Parasitária, Instistuto Oswaldo Cruz-Fiocruz, Av. Brasil 4365, 21045-900 Rio de Janeiro, RJ, Brasil *Disciplina de Parasitologia, Departamento de Patologia e Laboratórios, Faculdade de Ciências Médicas

**Departamento de Ciências Fisiolológicas, Instituto de Biologia Roberto Alcântara Gomes, Uerj, Rio de Janeiro, RJ, Brasil

The effect of streptozotocin-induced diabetes mellitus was studied in mice infected with Schistosoma mansoni. Faecal egg excretion was lower in diabetic mice but worm load and total amount of eggs in the intestine tissue were equal to the control group. Evaluation of an oogram showed a great number of immature dead eggs and a low number of mature eggs in diabetic mice. It was therefore concluded that faecal egg excretion was lower in diabetic mice due to impaired egg maturation.

Key words: Schistosoma mansoni - diabetes mellitus - oogram

Various changes in the host metabolism, like malnutrition (Ferreira \& Coutinho 1999), vitamin deficiency (Turchetti-Maia et al. 1983), and insulin-dependent diabetes mellitus (Mahmoud et al. 1975) have been described to affect schistosomiasis in laboratory animals. Insulin-dependent diabetes mellitus (IDDM) is a metabolic disease, which is caused by the absence or the impaired functionallity of insulin and is mainly characterized by high blood glucose concentrations. IDDM can be induced in laboratory animals by injection of chemicals, like streptozotocin (STZ) (Rerup \& Tarding 1969), which destroy the $\beta$-cells in the pancreas.

Diabetes mellitus is associated with some defects in the cell-mediated immunity (Mandel \& Mahmoud 1978) and individuals who suffer from this disease seem to be more susceptible to bacterial and fungal infections (Hart et al. 1969, Robertson \& Polk 1974). In several experiments performed by Mahmoud et al. $(1975,1976)$ and by Mahmoud (1979), chemically induced and ge-

\footnotetext{
${ }^{+}$Corresponding author and scholarship of Instituto Oswaldo Cruz. Fax: +55-21-587.6112. E-mail: hulstijn@ioc.fiocruz.br.

++ CNPq fellowship

Received 26 June 2000

Accepted 13 November 2000
}

netic diabetic mice were infected with Schistosoma mansoni. The results from these experiments showed that there was no difference between control and diabetic littermates in egg output, length and number of worms or in cercariae penetration through the skin. However, the size of the granuloma around the eggs, in both the liver and the lungs, was described to be smaller in diabetic mice. No difference was observed in granuloma formation around foreign bodies (divinyl benzene copolymer beads). These works show that IDDM affects the cell-mediated immune response around S. mansoni eggs in mice. On the other hand eosinophils favour the passage of schistosomal eggs to the intestinal lumen (Lenzi et al. 1987) and mice deprived of their T-cells have fewer eggs in their faeces (Doenhoff et al. 1978). Given that faecal egg excretion depends on the host immune response the present work was initiated to analise whether streptozotocin-induced diabetes mellitus could affect the faecal egg excretion.

Swiss Webster mice ( 5 days old) were infected transcutaneously by exposing them to 50 cercariae (BH strain) of S. mansoni. From 40 days after the infection on, faeces was collected twice a week from each mouse individually. The faeces were processed according to the Kato-Katz method (Katz et al. 1972) and two slides per animal were counted. Forty-seven days after infection, IDDM was induced in 20 mice with an average weight of $33.9 \pm$ $1.3 \mathrm{~g}$ by injecting STZ ( $180 \mathrm{mg}$ per kg bodyweight, ip.) dissolved in citrate buffer ( $\mathrm{pH} 4.5)$. Control 
mice were injected with citrate buffer only. Blood samples were taken from the tail three days after inducing IDDM and glucose concentrations were measured using Glucometer Elite test strips (Bayer). Among the 20 animals injected with STZ, three died and four had blood glucose concentrations below $120 \mathrm{mg} / \mathrm{dl}$ and were therefore excluded from the experiment. All animals were sacrificed 63 or 64 days after infection and worms were recovered from the portal and mesenteric veins by perfusion (Smithers \& Terry 1965). An oogram was made from the first centimetre of the distal part of the small intestine (Machado e Silva et al. 1991) and eggs were qualified according to criteria described by Prata (1957). Sixty eggs per oogram were randomly chosen and qualified. In total 12 oograms (6 of each group) were examined. The colon and the rest of the small intestine were dissolved in 4\% $\mathrm{KOH}$ (Cheever 1968) and the total number of eggs was determined. Student t-tests were used to compare the two groups (significant $\mathrm{p}<0.05)$.

The results (Table I) show that diabetic mice have a significant lower amount of eggs per gram faeces 57 and 61 days after infection. The signifi- cant lower counts appear ten days after STZ injection. This is in complete accordance with the normal time of ten days it takes between oviposition and faecal egg excretion. Similar amount of worms were recovered from the mesenteric and portal veins of control and diabetic mice. Also no difference was seen in the amount of male- or female worms. The egg counts in the intestine after dissolving the tissue with $4 \% \mathrm{KOH}$ showed no significant difference between the two groups, which demonstrates that the female egg production was not affected by STZ injection.

However the percentage of mature and immature eggs is rather different between both groups, as well as the percentage of live and dead eggs (Table II). In control mice 30\% of eggs is mature, while in diabetic mice this is only $7 \%$. The immature eggs in the diabetic mice are mostly dead and of the hemitransparent type. Among the $69.2 \%$ of dead immature eggs $52.4 \%$ is hemitransparent. Furthermore among the $17.1 \%$ live immature eggs only $2.8 \%$ belongs to the second till fourth stage of development.

According to Prata (1957) hemitransparent eggs are descended from first stage eggs only. This

TABLE I

Results (mean values \pm standard error) of blood glucose, egg excretion, worm load and number of eggs per $\mathrm{cm}$ intestine in diabetic and control mice

\begin{tabular}{lccc}
\hline & \multicolumn{2}{c}{ Group } & Significance \\
\cline { 2 - 3 } & $\begin{array}{c}\text { Diabetic } \\
(\mathrm{n}=13)\end{array}$ & $\begin{array}{c}\text { Control } \\
(\mathrm{n}=16)\end{array}$ & \\
\hline Blood glucose (mg/dl) & $364.7 \pm 24.1$ & $95.75 \pm 3.9$ & $\mathrm{P}<0.001$ \\
Egg excretion (eggs/g faeces) & $604 \pm 75.5$ & $777 \pm 177$ & $\mathrm{NS}$ \\
$\quad$ 50 days after infections & $706 \pm 160$ & $1096 \pm 150$ & $\mathrm{NS}$ \\
54 days after infections & $481 \pm 55.4$ & $1082 \pm 175$ & $\mathrm{P}<0.01$ \\
$\quad$ 57 days after infections & $453 \pm 71.7$ & $976 \pm 110$ & $\mathrm{P}<0.001$ \\
61 days after infections & $21.1 \pm 1.8$ & $19.7 \pm 1.6$ & $\mathrm{NS}$ \\
Worm load & $923 \pm 89.5$ & $832 \pm 117$ & $\mathrm{NS}$ \\
\hline Total number of eggs/cm intestine & \\
\hline
\end{tabular}

$a$ : both small intestine and colon, after $4 \% \mathrm{KOH}$ digestion; NS: not significant

TABLE II

Comparison of the percentage of different type of eggs in the distal part of the small intestine from diabetic and non-diabetic mice after 63 days of infection with Schistosoma mansoni

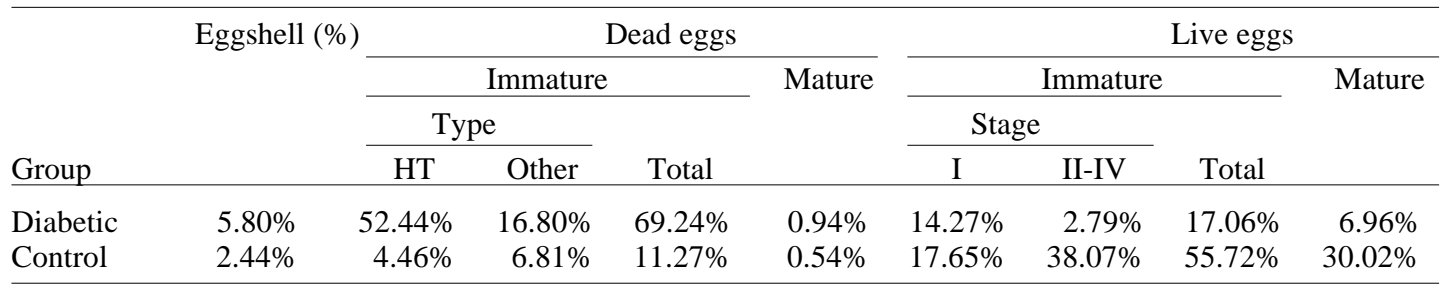

HT: hemitransparent egg; Other: either black, granular or non-definable egg 
means that egg maturation in the diabetic mice almost does not pass the first stage of development. The lower amount of the eggs per gram faeces is thus rather a result of an impaired maturation than of an impaired immune response.

Results from an oogram study in immunosuppressed mice performed by Hermeto et al. (1994), showed a higher total amount of eggs and a higher amount of dead eggs in the intestine. No alterations in the percentage of the different immature viable eggs were found, and the amount of mature eggs was even higher in the immunosuppressed mice. These data suggest that the egg passage through the intestine tissue was hampered but that the maturation did not seem to be affected after suppression of the immune response. On the other hand a study in malnourished mice performed by Akpom (1978) demonstrated that fewer eggs reached full maturity and more dead immature eggs were found when malnutrition was increased. These results are similar to the presented data. Apparently the host environmental changes caused by malnutrition or by STZ-induced IDDM have either an effect on the worm's ability to produce viable eggs, or on the development of the egg in the intestine tissue. In the six days of maturation while migrating through the host tissue the egg grows from $109 \mathrm{x}$ $51 \mu \mathrm{m}$ (first stage) to $148 \times 69 \mu \mathrm{m}$ (mature) (Prata 1957). Stjernholm and Warren (1974) showed that in the period after ovipostion eggs take up a wide range of exogenous metabolites in vitro. Metabolic changes caused by diabetes or malnutrition could thus affect the maturation in the host tissue. Microvascular intestinal changes associated to the diabetic state for instances might play a role. Nevertheless it seems more likely that production of viable eggs by the female worm is affected. Most eggs are already dead in the first stage of their development. A possible role for insulin in this sense seems doubtful since Clemens and Basch (1989) concluded that glucose uptake by the worm is insulin independent, because no insulin receptor was detected and high concentrations of insulin failed to affect glucose consumptions of worms in vitro. Non-enzymatic glycosylation of proteins due to hyperglycaemia cannot be discarded to influence the reproductive capacity of the female worm or the ability of the egg to mature.

Inducing diabetes mellitus with streptozotocin in mice infected with $S$. mansoni resulted in a lower number of eggs per gram faeces and a lower amount of mature and viable eggs in the intestine tissue. The total amount of eggs in the intestine and the amount of worms recovered was not affected. The lower faecal egg excretion in diabetic mice is thus caused by impaired egg maturation.

\section{ACKNOWELEDGEMENTS}

To Dr L dos Reis Corrêa for providing cercariae and to F Bastos for technical assistance.

\section{REFERENCES}

Akpom CA 1978. The oogram as a sensitive method of assessing the effect of dietary deficiency on the parasite in experimental schistosomiasis mansoni. Trop Geogr Med 30: 219-225.

Cheever AW 1968. Conditions affecting accuracy of potassium hydroxide digestion techniques for counting Schistosoma mansoni eggs in tissues. Bull WHO 39: 328-331.

Clemens LE, Basch PF 1989. Schistosoma mansoni: insulin independence. Exp Parasitol 68: 223-229.

Doenhoff M, Musallam R, Bain J, McGregor A 1978. Studies on the host-parasite relationship in Schistosoma mansoni-infected mice: the immunological dependence of parasite egg excretion. Immunology 35: 771-778.

Ferreira HS, Coutinho EM 1999. Should nutrition be considered as a supplementary measure in schistosomiasis control? Ann Trop Med Parasitol 93: 437-447.

Hart PD, Russell Jr E, Remington JS 1969. The compromised host and infection. II. Deep fungal infection. J Infect Dis 120: 169-191.

Hermeto MV, Bicalho RS, da Silva RE, de Melo AL, Pereira LH 1994. Oogram studies in mice infected with Schistosoma mansoni and treated with dexamethasone. Rev Inst Med Trop São Paulo 36: 99104.

Lenzi HL, Lenzi JA, Sobral AC 1987. Eosinophils favor the passage of eggs to the intestinal lumen in schistosomiasis. Braz, J Med Biol Res 20: 433-435.

Katz N, Chaves A, Pellegrino J 1972. A simple device for quantitative stool thick-smear technique in schistosomiasis mansoni. Rev Inst Med Trop São Paulo 14: 397-400.

Machado e Silva JR, Oliveira RMF, Rodrigues e Silva R, Maldonado Jr A, Rey L 1991. Roedores silvestres como modelos experimentais da esquistossomose mansônica: Akodon arviculoides (Rodentia: Cricetidae). Rev Inst Med trop São Paulo 33: 257-261.

Mahmoud AA 1979. Host-parasite relationship in schistosomiasis mansoni in the mutation diabetic mouse db/db. Am J Trop Med Hyg 28: 286-289.

Mahmoud AA, Cheever AW, Warren KS 1975. Streptozotocin-induced diabetes mellitus and the host-parasite relation in murine schistosomiasis mansoni. J Infect Dis 131: 634-642.

Mahmoud AA, Rodman HM, Mandel MA, Warren KS 1976. Induced and spontaneous diabetes mellitus and suppression of cell- mediated immunologic responses. Granuloma formation, delayed dermal reactivity and allograft rejection. J Clin Invest 57: 362-367.

Mandel MA, Mahmoud AA 1978. Impairment of cellmediated immunity in mutation diabetic mice $\mathrm{db} /$ db. J Immunol 120: 1375-1377.

Prata A 1957. Tipos de ovos de Schistosoma mansoni. In Biópsia Retal na Esquistossomose mansoni, Serviço Nacional de Educação Sanitária, Rio de Janeiro, p. 15-60. 
Rerup C, Tarding F 1969. Streptozotocin- and alloxandiabetes in mice. Eur J Pharmacol 7: 89-96.

Robertson HD, Polk Jr HC 1974.The mechanism of infection in patients with diabetes mellitus: a review of leukocyte malfunction. Surgery 75: 123-128.

Smithers SR, Terry RJ 1965. The infection of laboratory hosts with cercariae of Schistosoma mansoni and the recovery of adult worm. Parasitology 55: 695-700.
Stjernholm RL, Warren KS 1974. Schistosoma mansoni: utilization of exogenous metabolites by eggs in vitro. Exp Parasitol 36: 222-232.

Turchetti-Maia RM, Bambirra EA, Coelho PM, Moraes e Santos T, Vieira EC 1983.The association of Schistosoma mansoni infection with deficiency of vitamin A in mice. Rev Inst Med Trop São Paulo 25: 215-222. 